\title{
Immunohistochemical Expression of p63 in Ophthalmic Pterygium
}

\author{
Aliaa Bakra, Rasha M. Abdelkareemª, Eman M. S. Muhammad ${ }^{a}$, Gamal A. Radwan ${ }^{\text {, }}$, Sana \\ S. Kroosh ${ }^{\mathrm{c}}$ \\ ${ }^{\text {a }}$ Pathology Department, Faculty of Medicine, SohagUniversity. \\ ${ }^{\mathrm{b}}$ ophthalmology Department, Faculty of Medicine, SohagUniversity. \\ ${ }^{\mathrm{c}}$ Pathology Department, Faculty of Medicine, AssuitUniversity.
}

\begin{abstract}
:
Background: Pterygium is one of the most commonly occurring eye diseases. It is widely regarded as a degenerative condition. Pterygium shares some similarities with tumors, as active cell proliferation.. P63, a member of the p53 gene family is a transcription factor that is crucial for the development and maintenance of stem cells in stratified epithelia. It is present in the limbus and sustains the proliferative potential of limbal stem cells. This study aims to evaluate the pattern of p63 expression in cases of pterygia, and to correlate this pattern with their clinicopathological parameters.
\end{abstract}

Materials and methods: p63 immunostaining was studied in 52 specimens of nasal pterygia using avidin-biotin peroxidase method.

Results: p63 was expressed in $61.5 \%$ of cases with variation in its expression, strong $25 \%$, moderate $21.1 \%$, and mild in $15.4 \%$ of cases. There was significant increase in p63 expression in recurrent pterygia than in primary $(\mathrm{p}<0.03)$.

Conclusion: Pterygium is a disease of limbal stem cells as reinforces of P63 gene in the pathogenesis of pterygium could explain the triangular shape of pterygium and the high amount of recurrence.

Keywords: Pterygium, p63, stem cells.

Abbreviation: Transiantamplyfing cells (TACs), Limbal epithelial stem cells (LESCs), Fuchs flecks (FF), Conjunctival intraepithelial neoplasia (CIN).

\section{Introduction:}

Pterygium is one of the most commonly seen disease in ophthalmology.. Anatomically, the pterygium is composed of body, neck, head and a white-gray avascular subepithelial cap called (Fuch's Islands) (Chow et al., 2008).

Despite being a very common disease, the exact pathogenesis of pterygium is still not clearly understood. Historically, pterygia were Considered a degenerative disorder.
The most widely recognized etiological factor is ultraviolet radiation (Weinstein et al., 2002).

Some authors described pterygia as a proliferative disorder resembling an aberrant wound healing (Di Girolamo et al., 2004). However at 2010, pterygium was described as an uncontrolled cellular proliferation of the conjunctiva (Tsai et al., 2010). Almost at that date, it was hypothesized that it may be due to loss of limbal stem cells in its niche and their 
migration toward the cornea (Bai et al., 2010).

p63(a transcription factor belonging to the p53 gene family located on chromosome 3q27-29)had been proposed as a keratinocyte stem cell marker, normally expressed in the nuclei of keratinocytes with proliferative potential, including skin and cornea (Pellegrini et al., 2001).

It is present in the limbus and its expression was strong in limbalholoclones (stem cells) and weak in meroclones (young TACs), but was undetectable in paraclones (TACs)(Cheeet al., 2006). So, we conducted this study to evaluate the pattern of p63 expression in cases of pterygia, and to correlate this pattern with their clinicopathological parameter.

\section{Patients and methods:}

Patients and specimen collection: Fifty two nasal pterygia and three adjacent conjunctivae surgically excised and sent to Pathology Laboratory of Sohag University Hospitals from Sohag Ophthalmology Hospital at the period from 2016-2018 were included in the present study. Clinical data were obtained from the clinical reports.

\section{Immunohistochemistry:}

After evaluating (H\&E)stained slides. Serial sections from each block were used for immunohistochemistry. A dilution of 1:100 from Mouse monoclonal p63 antibody (clone 4A4 with catalog number \# CM163A, B, C, H. Biocare Medical Corporation) was used. Sections from skin were used as a positive control.

\section{Immunuohistochemical scoring:}

Scoring of p63 expression was performed by three pathologists. It appears as brownish nuclear staining. Semi-quantitative analysis of nuclear p63 immunoreactiviy was done with an immunoreactive score (IRS) system (Aliaa et al., 2018) modified from Fedchenko and

\section{Reifenrath, (2014).}

Firstly, the percentage of positive cells in two fields was scored with a 4-point scale: 0 for no positive cells, 1 for $<20 \%, 2$ for $20-50 \%$ and 3 for over $50 \%$. Secondly, the intensity of positive signal was scored with a 3-point scale; 0 for negative, 1 for faint, 2 for medium, and 3 for strong staining.

The IRS was calculated by multiplying the percentage of positive cells by the intensity of their staining. The IRS was: Negative (0-1), Weak (+) (2-3), Moderate (++) (4-6) and Strong (+++) (9).

\section{Statistical analysis:}

Data was analyzed using Statistical package for Social Sciences (SPSS) 16 for Windows.

\section{Results:}

\section{Demographic data:}

The mean \pm SD for patient's age was 46.33 \pm 13.34 . Most of the patients were males $34 / 52$ (65.4\%) while 18/52 (34.6\%) were females, with male: female ratio (M/F) 1.9: 1.

Pterygium characteristics in studied patients

Table 1. Histopathological findings

\begin{tabular}{|l|l|}
\hline Histopathological findings & $\begin{array}{l}\text { Summary } \\
\text { statistics } \\
\text { N(\%) }\end{array}$ \\
\hline $\begin{array}{l}\text { Inflammation } \\
\text { Mild } \\
\text { Severe }\end{array}$ & $31(59.6 \%)$ \\
\hline $\begin{array}{l}\text { Vascularity } \\
\text { Mild }\end{array}$ & $21(40.4 \%)$ \\
\hline Severe & $40(77 \%)$ \\
\hline $\begin{array}{l}\text { Dysplasia(figure 1) } \\
\text { No } \\
\text { Yes }\end{array}$ & $12(23 \%)$ \\
\hline
\end{tabular}

p63 expression and immunohistochemical findings (Table 2):

p63 expression appeared as brownish nuclear staining. 
Table 2. p63 expression in studied cases (Figure 2):

\begin{tabular}{|l|l|}
$\begin{array}{l}\text { Studied cases of } \\
\text { pterygium }\end{array}$ & $\begin{array}{l}\text { Summarystatistics } \\
(\%)\end{array}$ \\
\hline $\begin{array}{l}\text { p63 expression } \\
\text { Negative } \\
\text { Positive }\end{array}$ & $20(38.5 \%)$ \\
\hline $\begin{array}{l}\text { p63 expression grade } \\
\text { No }\end{array}$ & $20(31.5 \%)$ \\
Mild & $8(15.4 \%)$ \\
Moderate & $11(21.1 \%)$ \\
Strong & $13(25 \%)$ \\
\hline $\begin{array}{l}\text { Intensity of p63 } \\
\text { expression }\end{array}$ & $20(38.4 \%)$ \\
No & $8(15.4 \%)$ \\
Faint & $8(15.4 \%)$ \\
Moderate & $16(30.8 \%)$ \\
Strong & \\
\hline $\begin{array}{l}\text { Levels of p63 } \\
\text { expression } \\
\text { No }\end{array}$ & $20(38.5 \%)$ \\
Basal & $4(7.7 \%)$ \\
Basal and Parabasal & $15(28.8 \%)$ \\
All layers & $13(25 \%)$ \\
\hline
\end{tabular}

Table 3. Correlation of p63 expression in pterygium with the clinicopathological parameters

\begin{tabular}{|c|c|c|c|c|c|c|}
\hline \multirow{3}{*}{$\begin{array}{l}\text { Clinico- } \\
\text { pathologic } \\
\text { al } \\
\text { Paramete } \\
\text { rs }\end{array}$} & \multirow{3}{*}{$\begin{array}{l}\text { Ca } \\
\text { ses } \\
\text { No }\end{array}$} & \multicolumn{4}{|c|}{$\begin{array}{c}\text { P63 expression } \\
\mathrm{N}=52\end{array}$} & \multirow{3}{*}{$\begin{array}{c}\mathbf{p} \\
\text { valu } \\
\mathbf{e} \\
\end{array}$} \\
\hline & & \multirow[b]{2}{*}{$\begin{array}{l}\text { Neg } \\
\text { ativ } \\
\text { e } \\
N=2 \\
0\end{array}$} & \multicolumn{3}{|c|}{ Positive } & \\
\hline & & & $\begin{array}{l}\text { M } \\
\text { il } \\
\text { d } \\
\mathbf{N} \\
= \\
8\end{array}$ & $\begin{array}{c}\text { Mod } \\
\text { erat } \\
\text { e } \\
\mathrm{N}= \\
11\end{array}$ & $\begin{array}{c}\text { Str } \\
\text { on } \\
\mathrm{g} \\
\mathrm{N}= \\
13\end{array}$ & \\
\hline $\begin{array}{l}\text { Gender } \\
\text { Females } \\
\text { Males }\end{array}$ & $\begin{array}{l}18 \\
34\end{array}$ & $\begin{array}{c}8 \\
12\end{array}$ & $\begin{array}{l}2 \\
6\end{array}$ & $\begin{array}{l}4 \\
7\end{array}$ & $\begin{array}{l}4 \\
9\end{array}$ & $\begin{array}{l}0.88 \\
\text { (NS) }\end{array}$ \\
\hline $\begin{array}{l}\text { Type } \\
\text { Primary } \\
\text { Recurrent }\end{array}$ & $\begin{array}{c}46 \\
6\end{array}$ & $\begin{array}{c}20 \\
0\end{array}$ & $\begin{array}{l}8 \\
0\end{array}$ & $\begin{array}{l}9 \\
2\end{array}$ & $\begin{array}{l}9 \\
4\end{array}$ & $\begin{array}{c}<0.0 \\
3^{*}\end{array}$ \\
\hline
\end{tabular}

Chi-square test was used, $*=$ Significant, $\mathrm{NS}=$ Not significant

Table 4. Comparison of immunohistochemical parameters with type of pterygium

\begin{tabular}{|c|c|c|c|c|}
\hline \multirow{2}{*}{$\begin{array}{l}\text { Immunohistochemical } \\
\text { parameters }\end{array}$} & \multirow{2}{*}{$\begin{array}{c}\text { Cases } \\
\text { No } \\
(\mathbf{5 2})\end{array}$} & \multicolumn{2}{|c|}{ Type } & \multirow[t]{2}{*}{$p$ value } \\
\hline & & $\begin{array}{c}\text { Primary } \\
\mathrm{N}=46\end{array}$ & $\begin{array}{l}\text { Recurrent } \\
\qquad \mathrm{N}=6\end{array}$ & \\
\hline $\begin{array}{l}\text { Score grade } \\
\text { Negative } \\
\text { Mild } \\
\text { Moderate } \\
\text { Strong }\end{array}$ & $\begin{array}{c}20 \\
8 \\
11 \\
13\end{array}$ & $\begin{array}{c}20 \\
8 \\
9 \\
9\end{array}$ & $\begin{array}{l}0 \\
0 \\
2 \\
4\end{array}$ & $<0.005^{*}$ \\
\hline $\begin{array}{l}\text { Immunoreactive } \\
\text { score (IRS) }\end{array}$ & 52 & $3.24 \pm 3.6$ & $7.67 \pm 2.2$ & $<0.007^{*}$ \\
\hline $\begin{array}{l}\text { Intensity of p63 } \\
\text { staining } \\
\text { No } \\
\text { Faint } \\
\text { Moderate } \\
\text { Strong }\end{array}$ & $\begin{array}{c}20 \\
8 \\
8 \\
16\end{array}$ & $\begin{array}{c}20 \\
8 \\
7 \\
11\end{array}$ & $\begin{array}{l}0 \\
0 \\
1 \\
5\end{array}$ & $<0.004^{*}$ \\
\hline $\begin{array}{l}\text { Percentage of positive } \\
\text { cells } \\
\mathbf{0} \% \\
<\mathbf{2 0 \%} \\
\geq \mathbf{2 0 - 5 0 \%} \\
>\mathbf{5 0} \%\end{array}$ & $\begin{array}{c}20 \\
0 \\
12 \\
20\end{array}$ & $\begin{array}{c}20 \\
0 \\
10 \\
16\end{array}$ & $\begin{array}{l}0 \\
0 \\
2 \\
4\end{array}$ & $<0.05^{*}$ \\
\hline $\begin{array}{l}\text { Levels } \\
\text { No } \\
\text { Basal } \\
\text { Basal and parabasal } \\
\text { All layers }\end{array}$ & $\begin{array}{c}20 \\
4 \\
15 \\
13\end{array}$ & $\begin{array}{c}20 \\
4 \\
14 \\
8\end{array}$ & $\begin{array}{l}0 \\
0 \\
1 \\
5\end{array}$ & $<0.002 *$ \\
\hline
\end{tabular}

Mann-Whitney test was used, *=Significant 


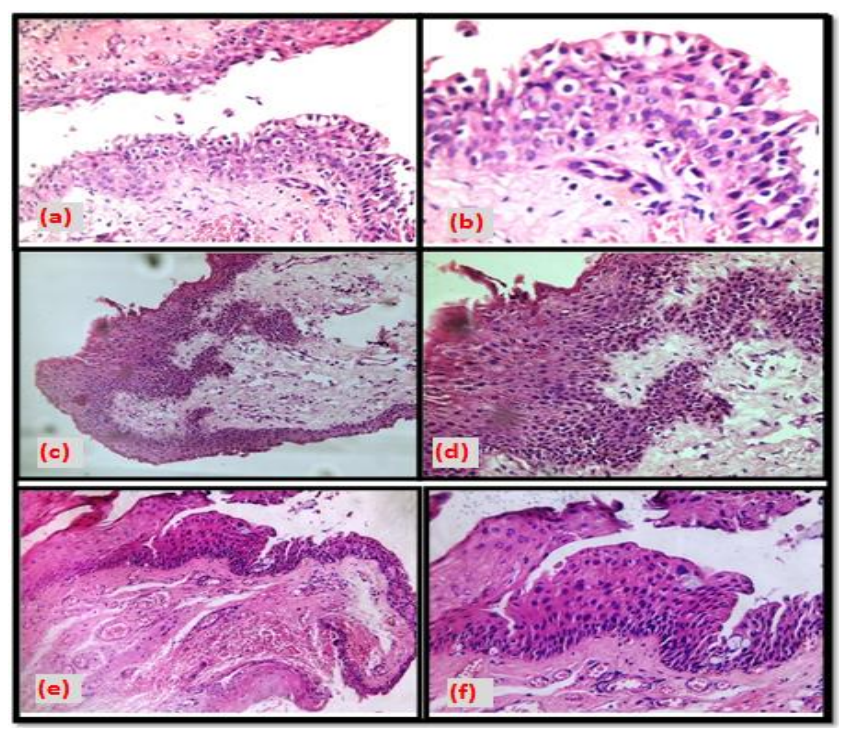

Figure 1. show dysplastic cases (CIN) in pterygia, H\&E. x200 (c and e); 400 (a, d and f); 800 (b).

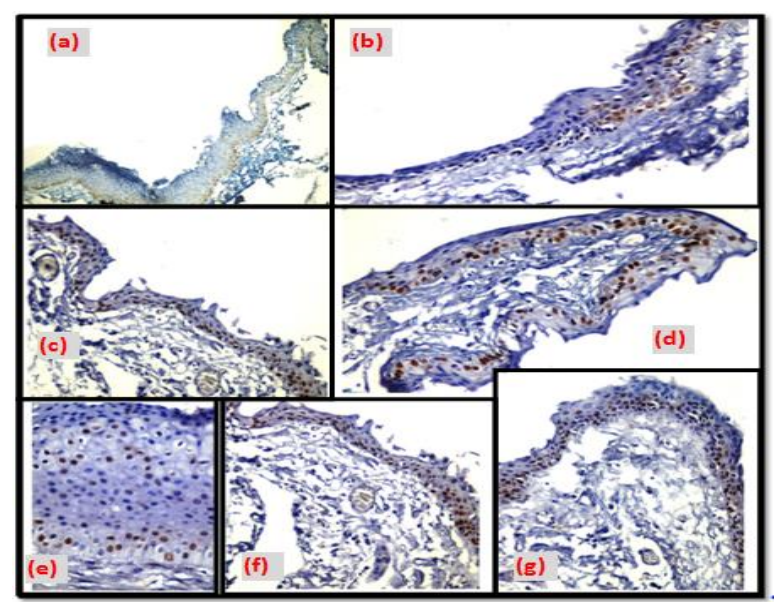

Figure 2. (a) The pterygium shows positive expression of p63 in all areas. (b) Another case shows different expression of p63 positive in area and negative in another area . (c, d, e, f, g) Different cases of pterygiashow positive p63 expression in all layers, x 40 (a); 200 (b, c, d, f and g); 400 (e).

\section{Discussion:}

Pterygia are common ocular surface lesions. Its prevalence revealed that the main risk factors were older age and a geographical location closer to the equator (Bikbov et al., 2019). our studyrevealed that pterygium is more common in adult and old age male due to more exposure to sun light and outdoor working in our country. Our findings were near to that reported by others as Chui et al., (2011), Nubile et al., (2013)and Rezvan et al., (2018).

In contrast, these studies found that male to female ratio was different (Ramalho et al., 2006) in Brazil and (Essuman et al., 2014)in Ghana These differences from our results may be due to spending longer hours outdoors by women in these countries.

Pellegrini and associates(2001) observed that in the limbus, p63 appears to be expressed in isolated basal epithelial cells and they suggested that p63 identifies limbal stem cells; so we used p63 as an indicator of stem cell presence.

In our study, the three cases of normal conjunctiva adjacent to pterygia and the 15 corneal epithelia showed negative p63 expression. The expression of p63 was positive in $32 / 52(61.5 \%)$ of pterygia. Our observations suggest that pterygia are of limbal stem cell origin. Our findings are similar to that previously reported in many studies as Di-Girolamo et al., (2003), (Atkinson et al., 2008) and (Nubile et al., 2013).

In our study, regarding the epithelial level, p63 expression was variable from the basement membrane upward. In agreement with our study Ramalho et al., (2006), Atkinson et al., (2008), Bai et al., (2010), Nubile et al., (2013)and $\mathrm{Xu}$ et al., (2014) reported variable expression of p63 in epithelial layers.

The study of (Bai et al., 2010) demonstrated the existence of stem-like cells, which express p63 in the head and body epithelia of pterygia 
and Nie et al., (2018) found that p63 expression is higher in body than in head and neck.

We have to acknowledge some limitations of our study that we couldn't identify the head, neck, and body pterygial parts separately.

We suggested that pterygium is due to a proliferation of limbal stem cells (pterygium cells) that lead to formation of head, neck and body parts of pterygium. Pterygium cells may proliferate and invade the corneal tissue as $\mathrm{X}$, $\mathrm{Y}, \mathrm{Z}$ pattern; which explain its triangular shape. However the proliferation of basal cells $(\mathrm{X})$ and the centripetal migration $(\mathrm{Y})$ is more than the shedding of superficial epithelial cells (Z).

In this study, we observed basal cell clusters in many p63 positive cases. Some of those cell clusters look in the resting stage and others are active and look 3-D like. Our findings come in concordance with Chui et al., (2011)and the study of (Matthew et al., 2015) identified clusters of cells in the zone of the cornea-like epithelium at the advancing pterygium head called Fuchs Flecks (FFs).

We found a significant increase in p63 expression in recurrent pterygia than in primary pterygia $(\mathrm{p}<0.03)$. There was also a significant increase in the percentage of positive cells, staining intensity and the IRS of p63 in recurrent pterygia compared to primary pterygia $(\mathrm{p}<0.05,0.004$, and 0.007 respectively). There was a significant difference in p63 expression in recurrent pterygia compared to primary pterygia regarding the epithelial levels $(\mathrm{p}<0.002)$ and stained area; focal versus multifocal $(\mathrm{p}<$ $0.05)$.

In recurrence increased p63 expression and its redistribution upwards could be explained at least partially by substitution of normal differentiated superficial epithelial cells by less differentiated cells and this confirm that pterygium is a disease of limbal stem cells. Our results were in agreement with Ramalho et al., (2006) study that revealed p63 expression in the basal and parabasal layers of primary pterygia and in the full thickness of the epithelium in recurrent pterygia.

\section{Conclusion:}

Pterygium is triangular in shape originating from abnormal proliferation of limbal stem cell and invasion of corneal tissue as $\mathrm{X}, \mathrm{Y}, \mathrm{Z}$ pattern. A substitution of normal differentiated superficial epithelial cells by less differentiated cells could explain the high incidence of recurrence in pterygium and this confirm that pterygium is a disease of limbal stem cells.

\section{References:}

Atkinson S. D, Moore J. E and Best R. M, (2008). 'P63 Expression in Conjunctival Proliferative Diseases : Pterygium and (LOC) Syndrome', Current Eye Research, 33, pp. 551-558.

Bai H, Teng Y, Wong L, Jhanji V and Pang Cand Yam G.H, (2010). 'Proliferative and migratory aptitude in pterygium', Histochem Cell Biol, 134, pp. 527-535.

Bikbov M. M, Zainullin R. M, Kazakbaeva G. M, Gilmanshin T, R, Salavatova V. F, Arslangareeva., et al. (2019). 'Pterygium Prevalence and Its Associations in a Russian Population: The Ural Eye and Medical Study', American Journal of Ophthalmology. Elsevier Inc.205:27-34.

Chee K. Y. H, Kicic A and Wiffen S. J, (2006). 'Limbal stem cells: The search for a marker', Clinical and Experimental Ophthalmology, 34(1), pp. 64-73.

Chow C. Y, Dunn S. P and Heidemann D. G, (2008). 'Ocular Surface Reconstruction', in Serdarevic, F. B. P. M. C. M. A. F. O. (ed.) 
Corneal Surgery Theory Technique and Tissue. 4th Editio. Elsevier-Mosby, pp. 187198.

Chui J, Coroneo M. T, Tat I. T, Crouch R, Wakefield D and Girolamo N. D, (2011). 'Ophthalmic pterygium: A stem cell disorder with premalignant features', American Journal of Pathology, 178(2), pp. 817-827.

GirolamoN. D, ChuiJ, Coroneo $M$ and Wakefield D, (2004). 'Pathogenesis of pterygia: role of cytokines, growth factors, and matrix metalloproteinases', ProgRetin Eye Res, 23(2), pp. 195-228.

Essuman V. A,Vemuganti G. $K$ and NdanuT. A, (2014). 'Epidemiology and recurrence rate of pterygium post', Ghanamedical journal, 48(1), pp. 39-42.

Fedchenko and Reifenrath, (2014). Different approaches for interpretation and reporting of immunohistochemistry analysis results in the bone tissue - a review. Diagnostic Pathology 9:221.

Matthew H, Chui J. J, Tat $\mathrm{L}$ and Coroneo M. T, (2015). 'Significance of fuchs flecks in patients with pterygium/pinguecula: Earliest indicator of ultraviolet light damage', Cornea, 34, pp. 1560-1563.

Nie C, Zhang X. C, Xu S. Y, Quan Y. D, Tang $Z$. $X$ and Lu R, (2018). 'Pterygial body epithelium domination of pterygial proliferation with TCF4 as a potential key factor', Int J Ophthalmol, 11(9), pp. 14671474.

Nubile M, Curcio C, Lanzini M, Calienno R, Lezzi M , Mastropasqua A, et al., (2013). 'Expression of CREB in Primary Pterygium and Correlation with Cyclin D1, ki-67', Ophthalmic Res, 50, pp. 99-107.
Pellegrini G, Dellambra E, Golisano O, Martinelli E, Fantozzi I, Bondanza S, et al., (2001). 'p63 identifies keratinocyte stem cells.' Proceedings of the National Academy of Sciences of the United States of America, 98(6), pp. 3156-61.

Ramalho, F. S and Ribeiro-silva A, (2006). 'Expression of p63 and p16 in primary and recurrent pterygia', Graefe's Arch ClinExpOphthalmol, 244, pp. 1310-1314.

Rezvan F, Khabazkhoob M, Hooshmand E, Yekta A, Saatchi $M$ and Hashemi H, (2018). 'Prevalence and risk factors of pterygium: a systematic review and metaanalysis', Survey of Ophthalmology. Elsevier Inc., 63(5), pp. 719-735. 20).

Tsai Y. Y, Chiang C. C, Yeh K. T, Lee H and Cheng Y. W, (2010). Effect of TIMP-1 and MMP in pterygium invasion. Cornea; 51 : 3462-3476.

Weinstein O, Rosenthal G, Zirkin H, Monos T, Lifshitz T and Argov S, (2002). Overexpression of p53 tumor suppressor gene in pterygia. Eye, 16: 619- 621.

Xu Y, Zahang L, Zou D, Liu Z, Shang X, Wu H,et al., (2014). 'Differential Expression and Function of Survivin During the Progress of Pterygium', Invest Ophthalmol Vis Sci, 55, pp. 8480-8487. 